The International Journal of Engineering and Science (IJES)

|| Volume || 6 || Issue || 3 || Pages || PP 21-31 || 2017 ||

ISSN (e): $2319-1813$ ISSN (p): $2319-1805$

\title{
Techno-Economic Analysis of Biomass Integrated Electricity Generation System
}

\author{
Seth Addai-Asante ${ }^{1}$, Tang $\mathrm{Hao}^{2}$ \\ ${ }^{1}$ College of Energy and Power Engineering, Nanjing University of Aeronautics and Astronautics, Nanjing \\ 210016, China \\ ${ }^{2}$ College of Energy and Power Engineering, Nanjing University of Aeronautics and Astronautics, Nanjing \\ 210016, China
}

\begin{abstract}
With Ghana's quest to accomplish a nationwide electrification where $100 \%$ of citizens will have access to electricity, various power projects are underway. However, in spite of the fact that there is an abundance of biomass resource, little attention has been paid to the potential of this resource in power generation. This paper discusses the energy potential of cocoa pod husks of which over a million tonnes are produced but wasted annually. A biomass integrated combined electricity generation system is simulated using cocoa pod husks as fuel with the aspen plus simulation software. An ORC and a bottoming Stirling Engine generator integrated into a biomass gasification plant generates $1.3 \mathrm{MW}$ of power at an overall plant efficiency of $36.69 \%$. A comparison with an existing $2.5 \mathrm{MW}$ solar power plant showed that although the total capital cost for the biomass integrated combined power plant was higher, it was more economical in the long term operations as the payback time for the difference in capital cost is approximately 12.55 years. The biomass integrated power plant however produces $1.98 \mathrm{GWh}$ more power than the solar power plant annually. Also it is realised that the national electricity production will be increased by $4.8 \%$ if all the cocoa pod husks are used biomass fuel to generate electricity using the same plant configuration and specifications.
\end{abstract}

Keywords - Biomass, Gasification, Organic Rankine Cycle (ORC), Stirling Engine, Cocoa Pod Husk.

Date of Submission: 02 March 2017

$\longrightarrow$ Date of Accepted: 28 March 2017

\section{INTRODUCTION}

Energy is an indispensable need for humanity and also the driving force for the development of every nation. Hence it is no surprise that governments and ordinary citizens take the issue of energy very serious. In recent years, Ghana has been facing a severe power crisis, which caused the country's power authority to roll out a massive power rationing scheme which has been running for years, resulting in severe erratic power supply in the country.

Ghana has an installed electricity capacity at 3,644 MW [1] and this effects into 75\% [2] of electricity access which happens to be one of the highest on the African continent. However, the country's target is to achieve $100 \%$ universal electrification by 2020 [3]. Reliability, stability and continuous production of electricity have been the main challenges to the power producers of Ghana and some of these challenges have been caused by fluctuating prices in crude oil, natural gas and liquefied petroleum gas, which are the main fuels used to power the country's thermal power plants.

The Ghana government has been pursuing a national electrification project connecting every city, town and village to the national grid. This is an ongoing project and there is still about a quarter of the population yet to be connected to the grid-based electricity. Most of the towns not connected are usually small communities which are remotely located and with very low living standards there exists a high level of poverty. This and other reasons have slowed down the construction of long distance transmission lines which are very expensive to connect these communities to the national grid. Most inhabitants of these villages and towns cannot even afford to pay the 'high' electricity tariffs. These towns and villages however produce in abundance biomasses being it in the forms of animal waste, agricultural waste and waste forest products.

Therefore, biomass energy production can help hasten this national electrification process at a lower cost due to abundance biomass resources in the country. The pie chart below gives the primary energy supply in Ghana. In the year 2000, a total of 6.2 million tonnes of oil equivalent primary energy (biomass) was produced in Ghana and this exceeds the yearly average of energy generated at the Akosombo and Kpong hydroelectric plants by eleven and half times [3]. 


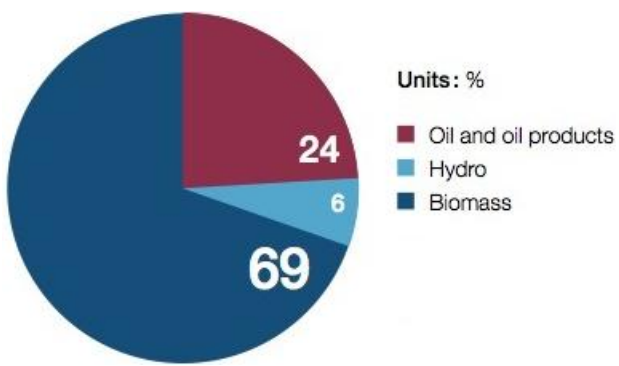

Figure 1 Primary Energy Supply Distribution In Ghana

Despite this fact that biomass remains and continues to be the number one primary energy supply in Ghana, biomass plays no role in the country's national overall electricity generation. TABLE 1 below gives the various electricity generation plants in Ghana and the fuel types used for their operation.

Table 1 Installed Electricity Generation Capacity [1]

\begin{tabular}{|l|l|l|l|l|}
\hline \multicolumn{2}{|l|}{ PLANT } & PRIMARY ENERGY & $\begin{array}{l}\text { INSTALLED } \\
\text { CAPACITY (MW) }\end{array}$ & SHARE (\%) \\
\hline Hydro & & & & \\
\hline & Akosombo & Water & 1,020 & 27.99 \\
\hline & Bui & Water & 400 & 10.98 \\
\hline & Kpong & Water & 160 & 4.39 \\
\hline Thermal & & & & 9.05 \\
\hline & Takoradi Thermal Power Plant & LCO / Natural Gas & 330 & 9.05 \\
\hline & Takoradi International Company & LCO / Natural Gas & 330 & 5.49 \\
\hline & Sunon Asogli Power Limited & Natural Gas & 200 & 3.02 \\
\hline & Cenit Energy Limited & LCO & 110 & 3.02 \\
\hline & Tema Thermal 1 Power Plant & LCO / Natural Gas & 110 & 1.37 \\
\hline & Tema Thermal 2 Power Plant & DFO / Natural Gas & 50 & 6.04 \\
\hline & Kpong Thermal Power Plant & HFO / Gas & 220 & 3.62 \\
\hline & Takoradi T3 & LCO / Natural Gas & 132 & 2.2 \\
\hline & Mines Reserve Plant & DFO / Natural Gas & 80 & 6.86 \\
\hline & Karpower Barge & HFO & 250 & 6.86 \\
\hline & AMERI Energy Power Plant & Gas & 250 & 0.07 \\
\hline
\end{tabular}

Although biomass is not used in the country's electricity generation it is however used significantly in the domestic sector for cooking and many other heat applications. Wood fuels, in the form of forest wood, charcoal and wood processing residues are the most dominant sources of biomass energy in use in Ghana. Agricultural wastes such as crop residue and other non-woody materials also find some insignificant usage in heating applications.

As evident from Figure 2, Ghana's biomass production has been increasing yet consumption has been fairly constant leading to massive and increasing biomass waste generation annually and most are in the form of woody forest and agricultural residue.

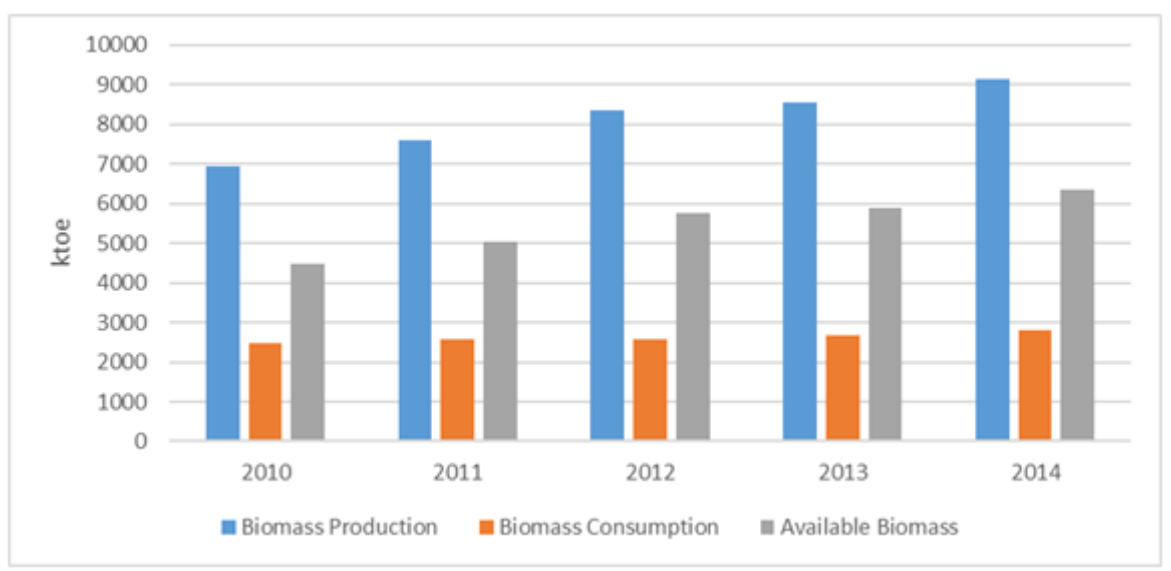

Figure 2 Biomass Production In Ghana [19] 
Obernberger et. al [4] designed an ORC integrated into a CHP system fuelled with biomass. This was a EU demonstration project in Lienz Austria. The ORC plant had an electric capacity of $1,000 \mathrm{~kW}_{\mathrm{el}}$ and was put into operation in 2001 and still in operation. Data from this project showed that such a plant can achieve a specific electricity production cost between USD $0.09 / \mathrm{kWh}$ and USD $0.14 / \mathrm{kWh}$. The paper stated however, that this cost depends on the fuel pricing conditions and the utilization of the plant. The cost of electricity production enables an economically viable application to be made in all countries they concluded.

Obernberger et. al again reviewed the work of [4] and also a $35 \mathrm{~kW}_{\mathrm{el}}$ biomass fuelled Stirling Engine generator. This plant like the one in [4], was a pilot project which was put into operation in 2002 and had run for over 4,300 hours by June 2003. The paper stated that the crucial economic performance of small-scale CHP plants are a high overall efficiency and high number of full load operations. It also noted that the total cost of electricity production is made up of about $60 \%$ capital cost only. The paper made mention of the state of some on-going projects on Stirling engine CHP in Europe and the USA of which a $75 \mathrm{~kW}_{\mathrm{el}}$ eight cylinder Stirling engine CHP was to be put into operation in summer of 2003.

Lane and Beale [6], designed and operated a prototype of a biomass-fired Stirling engine with a $1 \mathrm{~kW}_{\mathrm{el}}$ output for use in rural areas in South Africa. The generator is called BIOWATT ${ }^{\circledR}$. The paper stated that such generators can help meet South Africa's need for rural electrification and that is economically attractive alternative to central power station. In quantities of 10,000 units per year, the estimated production cost was USD 350 per unit. The engine's designed working hours was 40,000. This and other researches [7] have been done and some still ongoing but none has combined the ORC and Stirling Engine into a single combined power plant integrated into a biomass gasification system.

This paper attempts to simulate and analyse a biomass fuelled combined power plant that produces about $1.3 \mathrm{MW}$ of power for use in these remote communities of Ghana. The plant consists of a gasification unit which will gasify biomass into clean combustible gases (synthesis gas), an ORC plant and a bottoming Stirling engine plant. Techno-economic analysis will then be analysed and the results compared to $2.5 \mathrm{MW}$ solar power plants the only renewable power plant in Ghana.

\section{METHODOLOGY}

The commercial software Aspen Plus ${ }^{\circledR}$ version 8.8 was used to simulate a combined biomass gasification power plant with bottoming Stirling engine generator Figure 3. The main plant is an Organic Ranking Cycle operated plant and the plants overall power output is $1.3 \mathrm{MW}$.

The biomass feedstock used in the simulation is dried cocoa pod husk which is the main waste generated from cocoa harvest. Ghana produces on average 0.828 million metric tonnes [8] of dried cocoa bean for export annually since 2013 . Cocoa has a residue to product ratio of 0.93 and recoverability fraction of 0.80 . there is the potential of generating at least a 0.67 metric tonnes of total solids cocoa residue [10]. The proximate and ultimate analysis of cocoa on a dry ash free basis is given in the TABLE 2.

Table 2Elemental Analysis Of Cocoa Pod Husk [9]

\begin{tabular}{|c|c|c|c|}
\hline Ultimate Analysis & (wt.\%) & Proximate Analysis & (wt.\%) \\
\hline Carbon $(\mathrm{C})$ & 43.9 & Fixed Carbon (FC) & 11.6 \\
\hline Hydrogen $(\mathrm{H})$ & 5.8 & Volatile Matter (VM) & 76.4 \\
\hline Nitrogen $(\mathrm{N})$ & 2.2 & Ash & 12 \\
\hline Sulphur (S) & 0.5 & Moisture $^{\#}$ (M) & $20 \%$ \\
\hline Oxygen $(\mathrm{O})$ & 47.6 & HHV (MJ/kg) & 17.39 \\
\hline Ash & - & $\mathrm{LHV}^{*}$ (MJ/kg) & 15.77 \\
\hline
\end{tabular}

\section{PROCESS MODELLING AND SETUP CONFIGURATION}

Comparing a biomass furnace to a biomass gasifier and combustion system, biomass furnace is cheaper but its application is limited to external combustion heat applications whereas a biomass gasifier has a broader application spectrum in both external and internal combustion heat applications. Moreover, despite its initial investment costs and operations and maintenance costs, gasification gives higher yields [11]. Also other forms of biomass including animal waste cannot be used in a biomass furnace but can be gasified to produce biogas for power production. Moreover, gasification based system will return more revenue, has higher net present value and is more interesting when long time investment, more electricity and more revenue is considered over 20 years of its lifetime [31].

For these reasons, a biomass gasifier and combustion system integrated into an ORC with bottoming Stirling engine is considered in this paper. A bottoming Stirling engine eliminates the problem of sealing the power piston in the hot side cylinder of the Stirling engine due to high temperature and pressure [12]. Actual Stirling engines are based on piston-cylinder systems which are not readily available in Aspen Plus® however the simulation of the Stirling engine was adopted from the work of Megwai and Richards [13] who simulated the 
Stirling engine in Aspen Plus ${ }^{\circledR}$ version 8.4 and the Stirling engine consisted of a compressor, turbine, cooler and a heater but no regenerator. An ORC was chosen over a cheaper internal combustion engine due to the latter being inefficient as it converts only one-third of the fuel energy into mechanical work whereas the former is an efficient means of recovering heat [14]. Other reasons are the ORCs relatively quiet operation, small size, no emissions of exhaust gases $\left(\mathrm{CO}, \mathrm{CO}_{2}, \mathrm{NO}_{\mathrm{x}}\right)$ and other atmospheric pollutants and no need for severe and problematic gas cleaning process which ICEs require [15].

\section{GASIFICATION PROCESS}

Assumptions:

- The gasification occurs at the carbon boundary point (CBP) where all carbons are assumed to have been gasified [16]

- There is no pressure drop across the process

- Gasifying medium is air

- No heat loss across the gasifier

- Biomass particle size distribution was not considered

The following reactions are assumed to take place within the gasifier.

Table 3 Gasification Reactions [17, 18]

\begin{tabular}{|l|l|}
\hline Combustion zone & Reaction zone \\
\hline $\mathrm{C}+\mathrm{O}_{2} \rightarrow 2 \mathrm{CO}$ & $\mathrm{C}+\mathrm{CO}_{2} \rightarrow 2 \mathrm{CO}$ \\
$2 \mathrm{H}_{2}+\mathrm{O}_{2} \rightarrow 2 \mathrm{H}_{2} \mathrm{O}$ & $\mathrm{C}+2 \mathrm{H}_{2} \rightarrow \mathrm{CH}_{4}$ \\
& $\mathrm{CO}_{2}+\mathrm{H}_{2} \rightarrow \mathrm{CO}+\mathrm{H}_{2} \mathrm{O}$ \\
\hline
\end{tabular}

The property method selected was the Peng-Robinson equation of state with the Boston-Mathias modification. In Figure 3, biomass is modelled as a non-conventional solid with its proximate and ultimate analyses given in TABLE 2. The lower heating value (LHV) was also specified with the HCOALGEN and DCOALIGT property models chosen to estimate the biomass enthalpy of formation, specific heat capacity and density based on the ultimate and proximate analyses [9]. The thermodynamic conditions are 1 bar pressure and $25{ }^{\circ} \mathrm{C}$ temperature and the mass flow rate was calculated and entered. The MIXCINC stream class was chosen. This class is used for models where both conventional and non-conventional solids are present but no particle size distribution.

The biomass is fed into the RYield reactor, labelled, 'DECOMPSR' at a rate of $0.226 \mathrm{~kg} / \mathrm{s}$ and the reactor breaks down the non-conventional biomass into its conventional components and their mass yields were calculated and inputted based on the Ultimate Analysis. The biomass delivers a thermal input at nominal load of 3,564.02 kW. This RYield reactor is not a true standalone reactor but an integral part of the gasification reactor. The second reactor RGibbs, labelled 'GASIFIER' converts the decomposed biomass 'ELEMENTS' into synthesis gas 'RAW-SYNG' by reacting it with oxygen present in the 'AIR-GSFR' at standard temperature and pressure. The RGibbs reactor estimates the phase and chemical equilibrium by minimizing the Gibbs energy of the system. The gasification air ratio was calculated and an equivalence ratio of 0.23 was assumed [13]. The stream 'ELEMENTS' serves as a means to transfer the constituent elements of the decomposed biomass to the actual gasification reactor 'GASIFIER' and does not actually exist in reality. The heat stream 'HCOMB' links the two reactors in order to harness the energy required for the decomposition. Finally, and SSplit subroutine separates the stream 'RAW-SYNG' into solids 'ASH' present in the NC and CISOLID sub-streams and the gaseous product 'SYNGAS' in the MIXED sub-stream. The 'SYNGAS' is then fed into an RStoic reactor labelled 'COMBUSTR'.

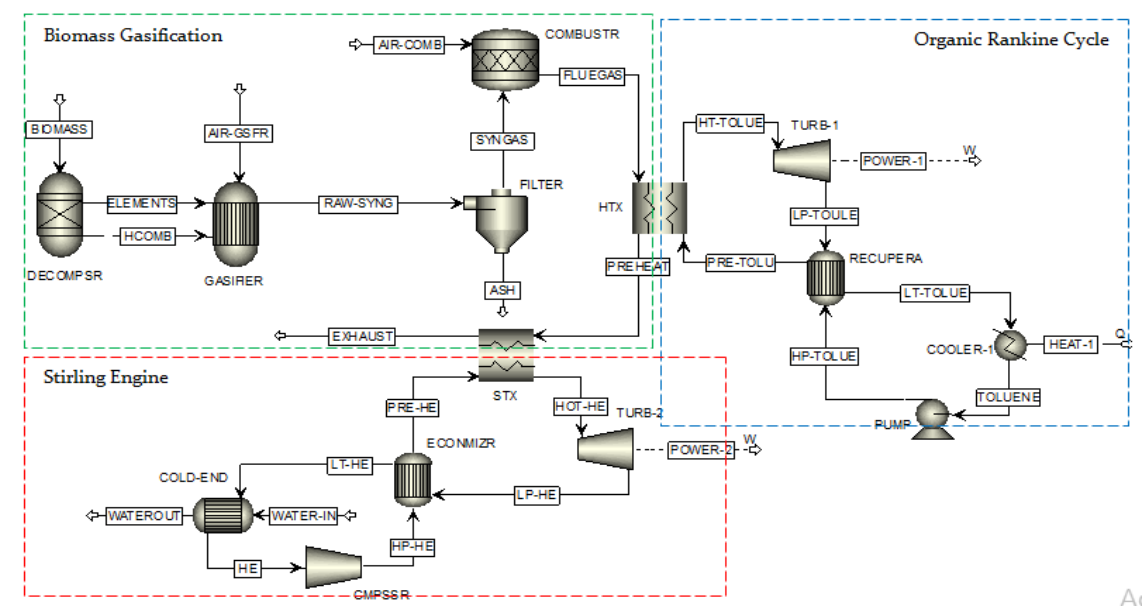

Figure 3 Biomass Integrated Combined Cycle Simulation Flowsheet 


\section{REGENERATIVE ORGANIC RANKINE CYCLE}

The principle of electricity generation by means of an ORC process corresponds to the conventional Rankine Cycle process. The substantial difference is that instead of water, an organic working medium with favourable thermodynamic properties is used as cited by [5]. The special advantage ORC has over conventional Rankine cycle are long service life, fully automated and unmanned operation (when necessary, only 3 to 5 hours per week) lowering its labour and maintenance cost.

Critical temperature and thermal stability among other criteria are factors to be considered when choosing a working fluid for an ORC application. Toluene has a very high critical temperature $\left(318.6{ }^{\circ} \mathrm{C}\right)$ and pressure 4126 $\mathrm{kPa}$ ) compared to other working fluids [19] making it suitable for the configuration considered in this paper. With reference to Figure 3, the following processes describe each state in the Organic Rankine Cycle In Aspen Plus ${ }^{\circledR}$, the syngas from the FILTER enters a combustor. The combustor is labelled COMBUSTR is an RStoic reactor. No chemical reactions were specified however the 'Generate Combustion Reactions' option was chosen. The combustion products FLUEGAS goes through the MHeatX heat exchanger labelled HTX. The MHeatX heat exchanger is modelled as the boiler of the ORC. The FLUEGAS exists HTX as EXHAUST. It heats up the ORC working fluid (Toluene) till its $100 \%$ vapour and temperature reaches $311^{\circ} \mathrm{C}$. The exchanger specification is set the value of the 'Cold Stream Outlet Vapour Fraction' to 1. The vaporised ORC working fluid then enters the turbine labelled TURB-1 where it expands generating mechanical work. The now low temperature low pressure ORC working fluid pre-heats the condensed working fluid from the pump in a regenerator labelled RECUPERA and its temperature further decreases before it enters the cooler labelled CONDENSR. The cooler is a Heater where the vapour fraction of the working fluid was set to 0 . Hence the fluid exits the cooler $100 \%$ liquid.

Table 4Properties Of Toluene [20]

\begin{tabular}{|l|l|l|}
\hline Property & Unit & Value \\
\hline Molecular weight & $\mathrm{g} / \mathrm{mol}$ & 92.14 \\
\hline Freezing point & ${ }^{\circ} \mathrm{C}$ & -94.965 \\
\hline Boiling point & ${ }^{\circ} \mathrm{C}$ & 110.629 \\
\hline Density at $20^{\circ} \mathrm{C}$ & $\mathrm{g} / \mathrm{cm}^{3}$ & 0.8667 \\
\hline Critical temperature & ${ }^{\circ} \mathrm{C}$ & 318.64 \\
\hline Critical pressure & $\mathrm{bar}$ & 41.09 \\
\hline Volume & $\mathrm{cm}^{3} / \mathrm{mol}$ & 316 \\
\hline Enthalpy of vaporization $\mathrm{H}^{0}$ vap & $\mathrm{kJ} / \mathrm{mol}$ & 38.06 \\
\hline Heat of formation & $\mathrm{kJ} / \mathrm{mol}$ & 12.00 \\
\hline
\end{tabular}

\section{STIRLING ENGINE GENERATOR CYCLE}

Stirling engines are based on a closed cycle where the working as is alternately compressed in a cold cylinder volume and expanded in a hot cylinder volume [5]. Compressible fluids such as air, hydrogen, helium, nitrogen or even vapours are suitable working fluids for the Stirling engine. Of these fluids, it's been found that hydrogen is the most efficient for improving power. However, hydrogen diffuses through materials and also poses the risk of inflammation and this makes it undesirable for safety reasons. Helium is thus more advantageous than the other gases $[12,21,22]$. With reference to the Figure 3 each process is discussed

Table 5Properties Of Helium [23, 24, 25]

\begin{tabular}{|l|l|l|}
\hline Property & Unit & Value \\
\hline Atomic number & & 2 \\
\hline Atomic mass & $\mathrm{g} / \mathrm{mol}$ & 4.0026 \\
\hline Density at $20^{\circ} \mathrm{C}$ & $\mathrm{g} / \mathrm{cm}^{3}$ & $-0.178 \mathrm{E}-3$ \\
\hline Melting point & ${ }^{\circ} \mathrm{C}$ & -272.2 \\
\hline Boiling Point & ${ }^{\circ} \mathrm{C}$ & -268.9 \\
\hline Molar Volume & $\mathrm{cm}^{3} / \mathrm{mol}$ & 21.00 \\
\hline Thermal Conductivity & $\mathrm{W} / \mathrm{m} . \mathrm{K}$ & 0.1513 \\
\hline Enthalpy of fusion & $\mathrm{kJ} / \mathrm{mol}$ & 0.02 \\
\hline Enthalpy of vaporization & $\mathrm{kJ} / \mathrm{mol}$ & 0.083 \\
\hline Critical temperature & ${ }^{\circ} \mathrm{C}$ & -267.96 \\
\hline
\end{tabular}

The combustion products FLUEGAS exits the boiler of the ORC as PREHEAT and enters the STX heat exchanger. This is also an MHeatX heat exchanger in Aspen Plus®. STX simulates the hot side cylinder of the Stirling engine. The temperature of PREHEAT is $980{ }^{\circ} \mathrm{C}$ which is high enough for an efficient Stirling ginee if the cold end is kept at a lower temperature since Stirling engine applications are suitable where a very good cooling source is available [20]. In the hot side cylinder, the working fluid Helium gains heat and its temperature rises till it reaches $950{ }^{\circ} \mathrm{C}$. It then expands through a polytropic turbine TURB-2 generation mechanical work. 
The polytropic turbine simulates the power piston of the Stirling engine. STX and TURB-2 together make up the hot end of the Stirling engine.

The working fluid then passes through a regenerator. The regenerator is modelled using a HeatX heat exchanger and labelled ECONOMZR. The regenerator stores $1,518 \mathrm{~kW}$ of heat at a temperature of $380^{\circ} \mathrm{C}$. The working fluid LT-HE now enters the cold side cylinder of the Stirling engine. For a higher efficiency, the temperature of the cold end cylinder should be as low as possible. In the simulation, it was kept at $90^{\circ} \mathrm{C}$. The cold end of the Stirling engine is modelled as a radiator labelled as PUMP and COOLER. The radiator made up of a heat exchanger and a water pump. The total work the pump does is a function of the cooling duty at the cold side. The higher the cooling duty, the higher the pump work input and lower the electrical efficiency of the Stirling engine. An ineffective radiator will also mean a low thermal efficiency for the Stirling engine. The working fluid HE from the COOLER enters into the polytropic compressor labelled CMPSSR. The compressor simulates the displacer of the Stirling engine. The mean working pressure of the working fluid is 46.5 bar.

\section{THERMODYNAMIC PERFORMANCE PARAMETERS}

\section{TECHNO-ECONOMIC ANALYSIS}

A means of indicating the gasifier performance is calculating its energetic efficiency or cold gas efficiency (CGE) or hot gas efficiency (HGE). The cold gas efficiency which is the commonly used gasifier performance indicator is the ratio between the chemical energy content in the product gas compared to the chemical energy in the fuel based on the lower heating value. It is given by the equation

$\mathrm{CGE}=\frac{\dot{\mathrm{m}}_{\text {gas }} \times \mathrm{LHV}_{\text {gas }}}{\mathrm{m}_{\text {biomass }} \times \mathrm{LHV}_{\text {biomass }}}$

The $\mathrm{LHV}_{\text {gas }}$ is calculated from the relation given in [14]

$\mathrm{LHV}_{\mathrm{gas}}=\mathrm{Y}_{\mathrm{CO}} \mathrm{LHV}_{\mathrm{CO}}+\mathrm{Y}_{\mathrm{H}_{2}} \mathrm{LHV}_{\mathrm{H}_{2}}+\mathrm{Y}_{\mathrm{CH}_{4}} \mathrm{LHV}_{\mathrm{CH}_{4}}$

where $\mathrm{LHV}_{\mathrm{CO}}=13.1 \mathrm{MJ} / \mathrm{m}^{\mathrm{a}} \quad \mathrm{LHV}_{\mathrm{H}_{2}}=11.2 \mathrm{MJ} / \mathrm{m}^{\mathrm{a}} \quad \mathrm{LHV} \mathrm{CH}_{4}=37.1 \mathrm{MJ} / \mathrm{m}^{\mathrm{a}}$

The thermal efficiency measures the thermal performance of the system and is defined as the ratio of the net power output to the thermal input of the feedstock is given by

$\eta_{\text {th }}=\frac{W_{\text {net,total }}}{\text { m}_{\text {biomass }} \times \mathrm{LHV}_{\text {biomass }}}$

$W_{\text {net, total }}=W_{\text {net, ORC }}+W_{\text {net } S E}$

$W_{\text {net } 0 R C}=W_{\text {TURB-1 }}-W_{\text {PUNP }}$

$W_{\text {net SE }}=W_{\text {TURB-2 }}-W_{\text {COMPRESSR }}$

Stirling engines however can reach higher thermal efficiencies since heat transfer occurs at constant temperatures, i.e., its thermal efficiency is same as the Carnot cycle assuming that the regenerator (ECONOMIZR) is perfect and dead volumes neglected. Therefore:

$\eta_{\text {th } S E}=1-\frac{T_{C E E}}{T_{H . E}}$

\section{ECONOMIC EVALUATION}

For the system discussed in this paper, a costing analysis is done to estimate the initial capital cost (ICC), the operating and maintenance cost $(\mathrm{O} \& \mathrm{M})$ and the fuel (biomass consumption) cost.

The cost of electricity production calculation can be grouped into 4 main types [4]

- Total capital cost (depreciation, interest costs)

- Consumption based costs (fuel, consumables)

- Operation based costs (labour costs, maintenance costs)

- Other costs (administrative, insurance)

Consumption based costs and operation based costs can be termed the working capital cost. 
An amortization factor $A_{f}$ used to amortize the cost of the sum of ICC over a 25-year period at a $5 \%$ interest/discount rate is calculated using the relation [19]

$A_{\mathrm{f}}=\frac{\mathrm{i}(\mathrm{i}+1)^{\mathrm{T}}}{(1+i)^{\mathrm{t}}-1}$

Operating and Maintenance costs $(\mathrm{O} \& \mathrm{M})$ are assumed to be a percentage to the initial capital cost. The general equations expressed below [19]

$$
\begin{aligned}
& \mathrm{TCC}=\mathrm{A}_{\mathrm{f}}(\mathrm{ICC}+0 \& \mathrm{M}) \\
& 0 \& \mathrm{M}=\mathrm{ICC}+\% 0 \& \mathrm{M}
\end{aligned}
$$

When the costs of a component are known but its capacity differs from that of the to-be-estimated component, the costs can be roughly estimated using the correlation known as the Capacity Exponent Ratio Method [26]

$\frac{c_{a}}{c_{b}}=\left(\frac{A_{a}}{A_{b}}\right)^{n}$

where $\mathrm{c}$ and $\mathrm{A}$ respectively represent the purchase costs and the equipment cost attribute of the required component $\left(c_{a}\right.$ and $\left.A_{a}\right)$ and the known component $\left(c_{b}\right.$ and $\left.A_{b}\right)$ and $n$ is the exponent used to correlate the costs. Equation (11) provides only rough approximations of the actual costs.

The costs of materials and labor are subject to inflation which implies cost figures from different years are not directly comparable. The most straightforward manner to update historical data is by means of composite cost indices, using the equation [26]

where $c_{j}$ and $c_{i}$ refer to the costs in year $j$ and $i$ respectively, and $I_{j}$ and $I_{i}$ are the cost indices for the respective years.

The cost of biomass (cocoa pod husk) can be computed from the relation [27]

$$
\text { cost of biomass per } \mathrm{kWh}=\frac{\text { (price of biomass) } \times \text { (specific fuel comsumption, SFC) }}{1000 \times(1-\text { percentage moisture })}
$$

The net present value (NPV) is the term used to evaluate a project while considering long term value of money. It is sum of present values which accounts for incomes minus costs for each period. The more positive the net present value is more value the project would add to the investment. It is given by the equation

$\mathrm{NPV}=\left(\mathrm{A} \times \mathrm{A}_{\mathrm{f}}^{-1}\right)-\mathrm{TCC}$

Payback time is the duration which the investment returns from benefit of project. It is interested that payback time be as low as possible. It is the ratio between initial investment and annual revenue. It can be computed using the relation [27]

Payback period $=\frac{\text { Total Capital Cost (USD) }}{\text { Uniform annual benefit (USD/year) }}$

\section{RESULTS AND DISCUSSION}

Table 6 Simulation Results

\begin{tabular}{|l|l|l|l|l|}
\hline Parameter & Gasifier & Organic Rankine Cycle & Stirling Engine & Overall \\
\hline Thermal Efficiency $(\%)$ & 77.64 & 23.06 & 70.31 (Carnot) & 36.69 \\
\hline Work Output $(\mathrm{kW})$ & - & $1,209.71($ TURB-1) & 347.48 (TURB-2) & $1,515.74$ \\
\hline Work Input $(\mathrm{kW})$ & - & 31.37 (PUMP) & $229.96($ CMPRESSR) & 235.883 \\
\hline Net Work Output $(\mathrm{kW})$ & - & $1,178.34$ & 123.52 & $1,301.86$ \\
\hline
\end{tabular}

The Stirling engine has a very thermal efficiency and it is within the range of various literature, however, its electrical efficiency is only $12.54 \%$ which is quite low but still within the range of various literature Cost of Biomass Per kWh of Electricity Generated 
Biomass electricity generation requires a feedstock that must be produced, collected, transported and stored. The economics of biomass power generation are critically dependent upon the availability of a secure, long term supply of an appropriate biomass feedstock at a competitive cost. [32] A typical cost structure for cocoa pod husks will be the collection cost, premium paid to farmers, transportation costs to the biomass power plant site and storage cost. Other factors like the moisture content and the preparation the biomass can be factored into the total biomass cost before being used as fuel for the power plant.

This power generation unit considered when running for 20 hours a day for 330 days a year will generate $1.3 \times$ $10^{\wedge} 6 \times 20 \times 330=8.58 \mathrm{GWh}$ annually.

Annual biomass consumption of the plant is 7,127.136 tonnes

The specific biomass consumption (SFC) is $=7,127,136 \mathrm{~kg} /$ year $\div 8.58 \times 10^{\wedge} 6 \mathrm{kWh} /$ year $=0.831 \mathrm{~kg} / \mathrm{kWh}$. In 2006, transportation for hauling fresh cocoa pod husk was USD 7.04 per ton which is equivalent to USD 7.76 per tonne. The premium paid to farmers which also includes collection cost was USD 0.002 per $\mathrm{kg}$ which is equivalent to USD 2.1 per tonne [28]. Taking into account the effect of inflation, these costs will be USD 9.2 per tonne for transportation and USD 2.5 per tonne for premium paid to farmers [29] making a total of USD 11.74 per tonne of cocoa pod husk.

Therefore, the cost of biomass per kilowatt of electricity generated is $(11.74 \times 0.831) \div\{1000-(1-0.35)\}=$ USD $0.015 / \mathrm{kWh}$ assuming a fresh cocoa pod husk contains $35 \%$ moisture. Initial Capital Cost for Plant Modules (Gasification Unit, ORC and Stirling Engine)

Also termed as the capital investment cost, this generally comprises of the costs directly associated with the system (equipment, materials, labour etc. required for the equipment and the installation thereof), indirect costs (engineering, construction costs and contingencies) and other outlays (such as start-up costs, working capital, etc.) This is the one-time cost occurring at the beginning of the project [26].

Gasification Unit

With reference to [26], the average specific capital cost of a $30-500 \mathrm{~kW}$ gasifier costs USD 500/kW. Using this a reference plant, the capital cost for the gasifier in this paper $(1,300 \mathrm{~kW})$ is estimated using equation (11) and the exponential index ' $n$ ' is taking to be 0.876 [26]. The specific capital cost for the gasifier is calculated to be USD 1,184.21/kW making a total cost equivalent to USD 1,421,052. The SIC for the gasifier unit is USD $0.166 / \mathrm{kWh}$.ORC Unit at the core of an ORC project's capital investment, are the components of the ORC module itself which includes the evaporator, expander and generator, condenser and pump. The costs for integration of the ORC module into a gasification unit vary according to the type of application. According to [26], biomass fired ORC projects are estimated the same order of magnitude as heat recovery systems.

Sanne Lemmens [26], estimated the ORC module specific investment cost (SIC) and the project specific investment cost using the capacity exponent ratio method with an exponent ' $n$ ' of 0.6 for his case study ORC plant used for heat recovery with reference plants with various power outputs, module specific investment cost and project investments costs discussed in other literatures. Results are tabulated in in TABLE 7. The case study ORC plant had an intermediate thermal oil circuit with an $11 \%$ share of the total investment cost.

Table 7Cost Estimates Using The Capacity Exponent Ratio Method

\begin{tabular}{|c|c|c|c|c|}
\hline $\begin{array}{l}\text { Reference Gross } \\
\text { Power (kW) }\end{array}$ & Reference Module SIC & $\begin{array}{l}\text { Reference Project } \\
\text { SIC }\end{array}$ & $\begin{array}{l}\text { Estimated Module } \\
\text { SIC }(\square 2012 / \mathrm{kW})\end{array}$ & $\begin{array}{l}\text { Estimated Project } \\
\text { SIC }(\square 2012 / \mathrm{kW})\end{array}$ \\
\hline 1100 & $1,818\left(€_{2012} / \mathrm{kW}\right)$ & $2,818\left(€_{2012} / \mathrm{kW}\right)$ & 2,796 & 4,334 \\
\hline 1300 & $1,154\left(€_{2012} / \mathrm{kW}\right)$ & $2,923\left(€_{2012} / \mathrm{kW}\right)$ & 1,897 & 4,806 \\
\hline 5300 & $943\left(€_{2012} / \mathrm{kW}\right)$ & $3,321\left(€_{2012} / \mathrm{kW}\right)$ & 2,721 & 9,579 \\
\hline 5400 & $1,148\left(€_{2012} / \mathrm{kW}\right)$ & $2,593\left(€_{2012} / \mathrm{kW}\right)$ & 3,337 & 7,535 \\
\hline 160 & $2,594\left(\epsilon_{2011} / \mathrm{kW}\right)$ & $3,375\left(\epsilon_{2011} / \mathrm{kW}\right)$ & 1,845 & 2,401 \\
\hline 250 & $2,080\left(€_{2011} / \mathrm{kW}\right)$ & $4,320\left(€_{2011} / \mathrm{kW}\right)$ & 1,769 & 3,673 \\
\hline 50 & $3,700\left(\mathrm{USD}_{2012} / \mathrm{kW}\right)$ & - & 1,653 & - \\
\hline 150 & - & $\begin{array}{l}12,596 \\
\left(\mathrm{USD}_{2012} / \mathrm{kW}\right)\end{array}$ & - & 8,731 \\
\hline 5500 & - & $\begin{array}{l}2,500 \\
\left(\mathrm{USD}_{2006} / \mathrm{kW}\right)\end{array}$ & - & 7,319 \\
\hline
\end{tabular}

For the ORC system discussed in this paper the project specific cost for a reference plant with an output of 1,300 $\mathrm{kW}$ will be chosen since it is the output closest to the power output of the discussed ORC. Considering an inflation rate of $4.64 \%$ [30] the project SIC will be (in 2016) $€ 5,028.95 / \mathrm{kW}$ which is equivalent to USD $5324.40 / \mathrm{kW}$ ( $€ 1=1.06$ USD). This will give an initial capital cost for the ORC unit (including labour and installation etc.) of USD 6,389,280.00. Since the ORC unit has no thermal oil circuit the net initial capital cost is USD 5,686,459.20. The specific initial capital cost for the ORC unit is USD $0.663 / \mathrm{kWh}$

Stirling engine generator 
The initial capital cost of a $35 \mathrm{~kW}$ Stirling engine is about $€ 250,000$ [15]. Extrapolating this cost with an exponent factor ' $n$ ' of 0.6 , the cost of the proposed Stirling engine in this paper is estimated using equation (11). The initial capital investment for a $124 \mathrm{~kW}$ Stirling engine proposed in this paper is $€ 534,013.45$ which is equivalent to USD 573,047.15 taking into account a 1.4\% inflation [29] and an exchange rate of $€ 1=1.06$ USD. The specific initial capital cost of the Stirling engine is USD $4,621.35 / \mathrm{kW}$ which is equivalent to USD $0.067 / \mathrm{kWh}$.

The total initial capital investment is the summation of initial capital costs of all systems; gasification unit, ORC system and Stirling engine generator, is equal to USD 7,809,255.35. This proposed system generates $8.58 \mathrm{GWh}$ of electricity annually and hence the specific initial capital cost is USD $0.91 / \mathrm{kWh}$ or USD $6,007.1 / \mathrm{kW}$.

Operations and Maintenance Expenditure $(\mathrm{O} \& \mathrm{M})$

Gasifier unit

The O\&M cost for the reference gasifier plant ranges between USD $0.007 / \mathrm{kWh}$ and USD $0.015 / \mathrm{kWh}$ [27]. The $\mathrm{O} \& \mathrm{M}$ cost of the gasification unit proposed in this paper can be estimated by extrapolating these figures using equation (11) and an exponential factor ' $\mathrm{n}$ ' of 0.6 . This gives a range between USD $0.018 / \mathrm{kWh}$ and USD $0.038 / \mathrm{kWh}$. Taking the average of these values gives an O\&M cost for the gasification unit to be USD $0.028 / \mathrm{kWh}$

$\mathrm{ORC}$ and Stirling engine generator unit

ORC and Stirling Engines have the advantage of being automated power plants with less maintenance [5, 32]. This advantage greatly reduces labour and maintenance costs. Operating and Maintenance costs (O\&M) are assumed to be a percentage to the initial capital cost [19].

Comparison with A 2.5 MW Solar Power Plant

The 2.5 MW solar plant in Navrongo in the Upper East region of Ghana is the first and only renewable energy source of the country as of now. New solar plants are currently under construction in the Central region of the country. The total capital cost of the plant is USD 8,082,028 [33]. This makes totals a specific cost of USD3,232.81/kW. At first glance it is realised this is a cheaper option to the biomass integrated combined plant.

Table 8 Proposed System Comparison With VRA Solar Plant

\begin{tabular}{|l|l|l|l|}
\hline Parameter & Unit & Proposed system & VRA solar power plant \\
\hline Total capital cost & USD & $7,809,255.35$ & $8,082,025$ \\
\hline Power Output & $\mathrm{kW}$ & 1,300 & 2,500 \\
\hline Specific initial cost & USD/kW & $6,007.1$ & $3,232.81$ \\
\hline Annual power generated & GWh & 8.58 & 6.6 \\
\hline Special annual cost & USD/GWh & $910,169.62$ & $1,224,549.24$ \\
\hline
\end{tabular}

The annual power generated is calculated from the assumption that the solar power plant works for 8 hours [21] in a day and 330 days in a year while the proposed system works for 20 hours a day and 330 days in a year. Since data on the operating and maintenance $(\mathrm{O} \& \mathrm{M})$ costs for the solar plant was not available, it will not be considered in this comparison.

From the TABLE 8 the specific initial cost for the proposed system is about twice that of the solar and this makes the proposed system expensive. However, the proposed system generates $1.98 \mathrm{GWh}$ more electricity annually. The saving made per GWh is 1,224,549.24 - 910,169.62 = USD 314,379.62. This makes an annual savings of USD 314,379/GWh $\times 1.98 \mathrm{GWh}=$ USD 622,471.65.

The net present value of the proposed plant over a period of 30 years is tabulated below. From the TABLE 9 it is evident that this plant will only be better than the solar plant when considering long term electricity generation which confirms the state in [31].

Table 9NPV Over A 30-Year Period

\begin{tabular}{|l|l|}
\hline Year & NPV (USD) \\
\hline 5 & $-5,114,278.86$ \\
\hline 10 & $-3,002,694.27$ \\
\hline 15 & $-1,348,212.49$ \\
\hline 20 & $-51,882.72$ \\
\hline 25 & $963,825.58$ \\
\hline 30 & $1,759,659.61$ \\
\hline
\end{tabular}

The NPV $=622,471.65 \times 14.094)-7,809,255.35=$ USD 963,860.09

The positive NPV value shows that the proposed plant is a better option to the solar power plant for long term electricity generation.

The PBP is USD 7,809,255.35/622,471.65 $=12.55$ years 


\section{CONCLUSION}

The results demonstrate that biomass is a very good potential for small scale power generation over a longer period of time. Biomass integrated combined power plant being a developing technology has more room for cost reduction. By 2020, gasification technologies using wood or waste wood as feedstock may achieve a capital cost reduction of about 22\% [32]. This cost reduction potential will make biomass integrated combined power plants more attractive and preferred to solar power plant with less initial capital cost. Also Ghana being the world's second largest producer of cocoa, cocoa pod husks as a biomass fuel can power biomass integrated combined power plants in Ghana for a longer period time that thus its reliable unlike solar where sun's energy is limited by time and weather. Biomass integrated combined power plant is a good option for small scale power generation in Ghana than solar. This biomass integrated electricity generating plant generates $8.58 \mathrm{GWh}$ of electricity annually with only $0.76 \%$ of the total cocoa pod husks generated in Ghana. Should $100 \%$ of all the waste biomass generated (cocoa pod husks) be channelled into electricity production using the plant described in this paper, a total output of $171 \mathrm{MW}$ of electricity will be generated which amounts to a total 1,272.6 GWh of electricity annually. This total output of $171 \mathrm{MW}$ of power output will increase the national power production by $4.8 \%$. This will also add value to cocoa as farmers will not only earn money on the cocoa beans they produce but also the husks as well.

\section{Nomenclature}

$\mathrm{C}$

$\mathrm{Y}$

$\mathrm{W}$

USD

GHC

$\mathrm{T}$

LHV

CBP

$\mathrm{m}$

VRA

LCO

DFO

$\mathrm{HFO}$

ICC

TCC

$\mathrm{R}$

i

$\mathrm{t}$

SIC

A

PBP cost (unless otherwise specified)

mole ratio

work rate

United States Dollar

Ghana Cedi (Ghana's currency)

Temperature

Lower Heating Value

Carbon Boundary Point

mass flow rate

Volta River Authority

Light Crude Oil

Diesel Fuel Oil

Heavy Fuel Oil

Initial Capital Cost

Total Capital Cost

Net benefit at a time

Interest/discount rate

Time in years

Specific Investment Cost

Equal end-of-year amount (USD)

Payback Period

\section{Subscripts}

$\begin{array}{ll}\text { gas } & \text { syngas } \\ \mathrm{CO} & \text { Carbon Monoxide } \\ \mathrm{H}_{2} & \text { Hydrogen } \\ \mathrm{CH}_{4} & \text { Methane } \\ \mathrm{ORC} & \text { Organic Rankine Cycle } \\ \mathrm{S} . \mathrm{E} & \text { Stirling Engine } \\ \text { th } & \text { thermal } \\ \text { el } & \text { electrical } \\ \mathrm{CE} & \text { cold end } \\ \mathrm{HE} & \text { hot end } \\ \mathrm{x} & \text { component }\end{array}$

\section{REFERENCES}

[1]. Power generation: facts and figures, available online www.vra.com/resources/fact.php accessed on July 15, 2016

[2]. Ghana Energy Commission, 2014 Energy (Supply and Demand) Outlook for Ghana. Online www.energycomm.gov.gh/files/Energy Commission-2014Energy Outlook for Ghana_final_2014.pdf accessed on July 16, 2016

[3]. Strategic National Energy Plan 2006 - 2020. Main Report. Energy Commission Ghana, online www.energycomm.gov.gh/files/snep/MAIN REPORT final PD.pdf accessed on July 16, 2016

[4]. I. Obernberger, P. Thonhofer and E. Reisenhofer, Description of a new 1000 kWlel Organic Rankine Cycle process integrated into biomass CHP plant in Lienz, Austria. Euroheat and Power, Volume 10/2002

[5]. I. Obernberger, H. Carlsen and F. Biedermann, State-of-the-art and future developments regarding small scale biomass CHP sstems with a special foucs on ORC and Stirling Engine technologies. International Nordic Bioenergy 2003 conference

[6]. N. W. Lane and W. T. Beale, A biomass-fired 1 kWel Stirling Engine generator and its application in South Africa. Sunpower Inc.

[7]. H. Damirchi, G. Najafi, S. Alizadehnia, B. Ghobadien, T. Yusaf and R. Mamat, Design, fabrication and evaluation of gamma-type Stirling engine to produce electricity from biomass for micro-CHP systems. The $7^{\text {th }}$ international conference on applied energy ICAE 2015, Energy Procedia 74 (2015) 137 - 143 
[8]. World cocoa production by country from 2012/2013 to 2015/2016 (in 1,1000 metric tons). Online https://www.statista.com/statistics/263855/cocoa-bean-production-worldwide-by-region

[9]. J. D. Martinez-Angel, R. A. Villamizer-Gallardo, O. O. Ortiz-Rodriguez, Characterisation and evaluation of cocoa (Theobroma cacao L.) pod husk as a renewable energy source. Agrociencia 49:329-345, 2015.

[10]. T. S. Tjalfe, O. Hanne, K. Zsofia, Bioenergy from agricultural residues in Ghana. PhD thesis, department of chemical and biochemical engineering, Technical University of Denmark

[11]. Velez, Segovia, Martin, Antolin, Chejne and Ana Quijiao. "A Technical, Economical and Market Review of Organic Rankine Cycle for the Conversion of low grade heat for Power Generation". Renewable and Sustainable Energy Reviews 16(2012) 4175 - 4189

[12]. Stirling Engine Advantages and Disadvantages; http://www.robertstirlingengine.com/advandisadvan.php

[13]. G. U. Megwai and T. Richards. “A Techno-Economic Analysis of Biomass Power Systems Using Aspen Plus”. International Journal of Power and Renewable Energy Systems (IJPRES) Volume 3, Issue 2, 2016

[14]. Quoilin, Van Den Broek, Dewallef and Vincent Lemort. "Techno-economic Survey of Organic Rankine Cycle (ORC) Systems". Renewable and Sustainable Energy Reviews 22(2013) 168 - 186

[15]. Cotana, Messineo, Petrozzi, Coccia, Cavalaglio and Andrea Aquino. "Comparison of ORC Turbine and Stirling Engine to Produce Electricity from Gasified Poultry Waste". Sustainability 2014, 6, 5714; doi; 10.3390/su6095714

[16]. K. J. Ptsasinski, M. J. Prins and Anke Pierik. "Exergetic Evaluation of Biomass Gasification". Energy 32(2007) 568 - 574

[17]. A. K. Rajvanshi, biomass gasification, in D. Yogi Goswami (Ed.), Alternative energy in agriculture, Vol II (CRC Press, 1986 , pgs 83 $-102)$

[18]. W. Dohety, A. Reynolds and D. Kennedy, Aspen plus simulation of biomass gasification in a steam blown dual fluidised bed. Book chapter; Material and processes for energy: communicating current research and technological development, A Mendez - Vilas (Ed.), Formatex Research Centre, 2013

[19]. Darvish, Ehyaesi, Atabi and Marc A. Rosen. "Selection of Optimum Working fluids for Organic Rankine Cycle by Exergy and Exergy-Economic Analyses". Sustainability 2015, 7, 15383; doi; 10.3390/su71115362

[20]. Properties of Toluene http://www.sbioinformatics.com/design_thesis/Toluene/Toluene_Properties\&uses.pdf

[21]. B. Kongtragool and S. Wongwises. "A Review of Solar-Powered Stirling engine and Low Temperature Differential Stirling engine". Renewable and Sustainable Energy Reviews 7(2013) 131 - 154

[22]. S. A. Musmar and I. Tlili. "Numerical Investigation of Working Fluid Effects on Stirling engine Performance". International Journal of Thermal and Environmental Engineering. Volume 10 No. 1(2015) 31 - 36

[23]. Chemical Properties of Helium - Health effects of helium http://www.lenntech.com/periodic/elements/he.htm

[24]. Helium: Physical Properties https://www.webelements.com/helium/physics.html

[25]. Helium: Enthalpies and Thermodynamics https://www.webelements.com/helium/thermochemistry.html

[26]. S. Lemmens. "Cost Engineering Techniques and their Applicability for Cost Estimation of Organic Rankine Cycles Systems". Energies 2016, 9, 485; doi: 10.3390/en9070485

[27]. P. W. Olupot, A. Candia, E. Menya and R. Walozi. "Characterization of rice husk varieties in Uganda for biofuels and their technoeconomic feasibility in gasification”. Chemical Engineering Research and Design 107 (2016) 63 - 72

[28]. D. K Adomako. "Project on Pilot plants to Process Cocoa by-products". Summry report presented to the execute committee of ICCO (International Cocoa Organization) at the $131^{\text {st }}$ meeting. London http://www.icco.org/about-us/international-cocoaagreements/doc_download/194-pilot-plants-to-process-cocoa-by-products.html

[29]. Inflation Calculator http://www.usinflationcalculator.com/

[30]. The European Union Inflation Calculators https://www.statbureau.org/en/european-union/inflation-calculators

[31]. R. Rowshanzadeh. "Performance and Cost Evaluation of Organic Rankine Cycles at Different Technologies". A Master Thesis, Department of Energy Technology, KTH Royal Institute of Technology, Sweden.

[32]. H. Damirchi, G. Najafi, A. Alizadehnia, B. Ghobadian, T. Yusaf and R. Mamat. "Design, Fabrication and Evaluation of GammaType Stirling Engine to Produce Electricity from Biomass for micro-CHP Systems". Energy Procedia 75 (2015) 137 - 143

[33]. Biomass for Power Generation, Renewable energy technologies: cost analysis series volume 1: Power sector, Issue 1/5. International Renewable Energy Agency (IRENA) June, 2012

[34]. online: www.vra.com/our_mandate/solar_energy.php accessed on July 8, 2016 